\title{
Investigation on the Effect of Cyclic Moisture Change on Rock Swelling in Hydropower Water Tunnels
}

\author{
Lena Selen ${ }^{1}$ (1) $\cdot$ Krishna Kanta Panthi $^{1} \cdot$ Maximiliano R. Vergaraa ${ }^{2,3} \cdot$ Mai Britt Mørk $^{1}$
}

Received: 15 May 2020 / Accepted: 29 September 2020 / Published online: 10 October 2020

(c) The Author(s) 2020

Keywords Rock swelling $\cdot$ Cyclic moisture change $\cdot$ Oedometer test $\cdot$ Water tunnel $\cdot$ Rock texture

\section{Introduction}

Swelling of rocks is often forecasted by the content of swelling clay minerals or anhydrite; however, the intensity of the expansion and subsequent swelling pressure cannot be attributed only to these rock constituents (Ruedrich et al. 2010). Rocks show a wide range of grain sizes, porosities and fabrics which can act as controlling factors on the swelling behavior upon ingress of water (Russell 1982; Olivier 1991; Dick and Shakoor 1992). In addition, the interaction between the rock material properties and the constructionspecific exposure to degrading agents controls important swelling characteristics of the weak and weathered rock mass. The surrounding rock mass on the periphery of hydropower water tunnels is unloaded and drained during tunnel construction and then the tunnel is exposed to cyclic wetting and drying processes during the operational lifetime of the project (Selen et al. 2019). This may lead to time-dependent changes in the rock mass properties aggravating risk on tunnel instability. Hence, the extensive moisture fluctuations are special features of hydropower water tunnels compared to other tunneling projects which seldom are addressed in laboratory testing procedures.

Several laboratory testing methodologies have been developed to determine the swelling behavior of rocks and the induced pressure from the rocks on their surroundings, as

Lena Selen

lena.selen@ntnu.no

1 Department of Geosciences and Petroleum, Norwegian University of Science and Technology (NTNU), Trondheim, Norway

2 Tunnel Engineering, Ed. Züblin AG-Zentrale Technik, Stuttgart, Germany

3 Institute of Soil Mechanics and Rock Mechanics, Karlsruhe Institute of Technology (KIT), Karlsruhe, Germany tunnel linings. According to Grob (1972), the swelling strain can be expressed as a function of the swelling pressure and is expressed as a linear relationship in a semi-logarithmic diagram. The so-called "Grob`s law" can be assessed by use of oedometer tests and assumes that the material behaves linear elastically and increases in volume as the applied stresses decrease (Einstein 1994). ISRM $(1989,1999,1979)$ has suggested different oedometer swelling tests, including a maximum swelling pressure test. The test measures the maximum pressure induced by a prepared rock disk after water immersion when volume expansion is hindered. However, the long-term swelling characteristics of a weathered rock mass surrounding a water tunnel may not be addressed using this method due to the intricate interaction between the rock properties and the cyclic moisture change during operation.

This manuscript investigates the interaction between cyclic wetting and drying, material composition/structure and swelling potential of weathered rocks. Laboratory tests were performed at the Norwegian University of Sciences and Technology (NTNU) and the Karlsruhe Institute of Technology (KIT). The rocks tested are of sedimentary and volcanic origin and were sampled from the headrace tunnels of two different hydropower projects located in Albania and the Philippines. Both headrace tunnels will experience a medium static water head of about $60 \mathrm{~m}$ at a base load of operation. However, hydropower plants of modern age are seldom operated to their base load due to power demand in the market, which causes fluctuation in the operation regime of the power plants. To determine the effect of moisture fluctuations on the swelling behavior of weathered rocks surrounding water tunnels, repeated wetting and drying cycles of swelling tests were performed on intact rock samples. The effect of unloading and thus allowing stagewise deformation to occur, as is the case in rock mass of shotcrete supported water tunnels, was comprehended in the 
testing procedure. Maximum swelling pressure tests on both pulverized and intact rock samples were included in the testing program. A comparison of the swelling test results is presented and correlated to the compositional and structural characteristics of each sample obtained by XRD and thin-section analyses. Finally, the effect of cyclic moisture change on the rock swelling is discussed in the context of long-term stability and support assessment of hydropower water tunnels.

\section{Brief on the Tested Rocks and Test Methods}

An overview of the testing and analyses carried out is given in Table 1. An assessment of the mineralogical composition and textural features was performed on all samples using XRD and thin-section analyses. Maximum swelling pressure tests on intact rock specimen and on samples made of compacted rock powder were obtained, whereby the intact specimen additionally underwent cyclic wetting-drying tests with controlled deformation.

\subsection{Tested Rocks}

A total of 14 samples were chosen for laboratory testing; 7 flysch rock samples from Albania and 7 volcanic rock samples from the Philippines (Table 2). Intact rock specimens for the oedometer swelling tests and thin-section analysis were prepared from the samples which did withstand the preparation, i.e., all volcanic and three flysch rock samples. Powder swelling tests were performed on all 14 rock samples (Fig. 1). All the prepared samples have a diameter of about $60 \mathrm{~mm}$.

\subsection{Mineralogical Investigation by XRD}

$\mathrm{X}$-ray diffraction (XRD) analysis is carried out to identify and determine the mineralogical composition of the tested rock samples by comparing relative peak heights of the crystalline phases. The XRD analysis may not fully recognize clay and clay-like amorphous components in weathered and altered rocks, since the original crystalline structure may be broken or altered into non-crystalline intermediates, including different sub-groups of swelling clays (Banfield and Eggleton 1990). Both natural

Table 1 Summary of performed tests

\begin{tabular}{|c|c|c|c|c|}
\hline \multirow[t]{2}{*}{ Methods } & \multirow[t]{2}{*}{$\mathrm{XRD}$ analysis } & \multicolumn{2}{|l|}{ Swelling tests } & \multirow[t]{2}{*}{ Thin-section analysis } \\
\hline & & Powder & Intact & \\
\hline Samples tested & $\begin{array}{l}7 \text { flysch samples } \\
7 \text { volcanic samples }\end{array}$ & $\begin{array}{l}7 \text { flysch samples } \\
7 \text { volcanic samples }\end{array}$ & $\begin{array}{l}3 \text { flysch samples } \\
7 \text { volcanic samples }\end{array}$ & $\begin{array}{l}3 \text { flysch samples } \\
7 \text { volcanic samples }\end{array}$ \\
\hline Aim of test & Mineralogical composition & Maximum swelling pressure & $\begin{array}{l}\text { Maximum swelling pressure and pres- } \\
\text { sure evolution at cycles with controlled } \\
\text { deformation }\end{array}$ & $\begin{array}{l}\text { Structural and miner- } \\
\text { alogical characteri- } \\
\text { zation }\end{array}$ \\
\hline
\end{tabular}

Table 2 Overview of the rocks and the prepared samples

\begin{tabular}{llll}
\hline Rock type & Specimen name & Description & Preparation/testing condition \\
\hline Flysch & Flysch A & Clay-/siltstone, highly disturbed, fractured & Powder \\
& Flysch B & Claystone-/siltstone, highly disturbed, crumbly & Powder \\
& Flysch C & Alternating claystone/siltstone & Powder and intact \\
& Flysch D & Intact claystone & Powder and intact \\
& Flysch E & Siltstone, intact & Powder and intact \\
& Flysch F & Claystone, disturbed & Powder \\
Flysch G & Claystone-/siltstone, highly disturbed & Powder \\
Volcanic & Volcanic A & Altered volcanic rock, intact, strong & Powder and intact \\
& Volcanic B & Basaltic rock, intact, strong & Powder and intact \\
& Volcanic C & Altered volcanic rock, intact, weak & Powder and intact \\
& Volcanic D & Altered volcanic rock, intact, strong & Powder and intact \\
Volcanic E & Volcanic breccia, intact, weak & Powder and intact \\
& Volcanic F & Volcanic breccia, intact, weak & Powder and intact \\
& Volcanic G & Altered volcanic rock, intact, weak & Powder and intact \\
\hline
\end{tabular}




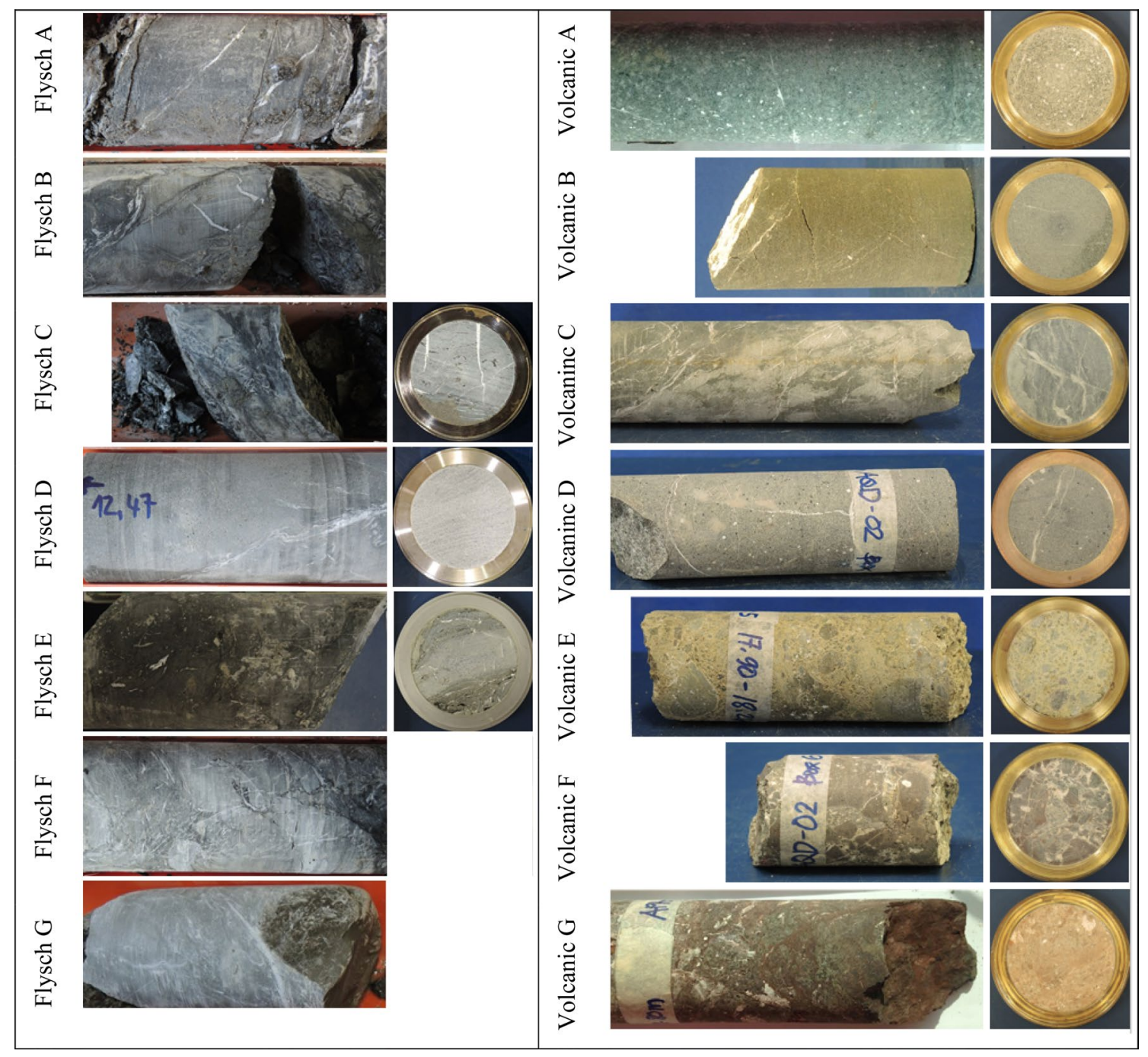

Fig. 1 Flysch rock samples from Albania (left) and Volcanic samples from the Philippines (right)

degradation of crystalline structures, as weathering and mineral transformations, and destructions of weak constituents during preparation may result in amorphous material. Different methods exist among analysts on how the results are calculated if the amorphous constituents are present.

For the volcanic rock samples from the Philippines, the samples were prepared and analyzed at NTNU. The preparation was performed by grinding the rock to a sieve size of $<0.020 \mathrm{~mm}$ and the samples were analyzed using a Bruker D8 ADVANCE. The identification of crystalline phases was carried out with the DIFFRAC.SUITE.EVA software combined with the PDF-4 + database. Quantification of the minerals was performed by Rietveld refinement in Topas, normally with an accuracy of 1-2\%. Glycolation was used on fraction sizes of $<6 \mu \mathrm{m}$ to identify swelling clays. Quantification on the amount of swelling minerals or differentiation between clay minerals is not a standard procedure at NTNU, nor is the amorphous phases indicated.

The flysch samples from the Albania were prepared and examined at KIT. The quantification of the crystalline phases was made using the Rietveld calculation. Through this process, $\mathrm{X}$-ray amorphous, nanocrystalline and organic components may elude the determination and affect the overall material content. Therefore, the standard procedure at KIT is to carry out a semi-quantitative determination of the different types of clay minerals by XRD on texture slides. The reported percentage of minerals include estimated amount of swelling minerals and amorphous phases, in addition to deviating between different types of clay minerals. 


\subsection{Structural and Textural Assessment by Thin-Section Analysis}

The thin-section analyses were performed at NTNU. The rock specimens were impregnated with blue epoxy aiming to detect open discontinuities and pores. An initial inspection of the samples was carried out by transmitted light microscopy of polished thin sections using a Nikon Eclipse E600 microscope. Optical micrographs were studied using parallel and cross-polarized light. The textural features were described by studying thin sections in an Olympus BX51 microscope. Scans were obtained by stitching $5 \times$ microscope images together using the Olympus stream motion and the Märzhauser Wetzlar automated stage. The porosity was qualitatively estimated by studying the thin-section scans of each sample. The findings were combined with the results from XRD analyses and the swelling potential was qualitatively estimated, aiming to compare the mineralogical/ structural features in the evaluations of swelling test results. The content of clay minerals was also estimated based on this method.

\subsection{Oedometer Swelling Tests}

The oedometer swelling tests were performed at KIT. Two different configurations of the oedometer swelling test were applied; (1) maximum swelling pressure test (ISRM 1999) and (2) the cyclic swelling test with controlled deformation (Vergara and Triantafyllidis 2015). The maximum swelling pressure test was performed on both powder and intact rock specimens, whereas the cyclic oedometer test was applied on the intact rock specimen. The tests were performed with the apparatus configuration, as shown in Fig. 2. In the laboratory, the apparatus is kept in an acclimatized room with a constant temperature of $20^{\circ} \mathrm{C}$ and with a relative humidity of $40 \%$.

The rock specimens were prepared from core samples, whereby a disk was cut from the drill core and trimmed using a lathe to make faces flat and parallel to each other so that the sample fits into the oedometer ring. The apparatus (Fig. 2) allows control of the vertical deformation and load on the specimen using a manual spindle. Demineralized water was added to the watering cell to activate swelling. During this phase, the vertical deformation of the specimen was hindered and kept to zero, while the load was measured over time. In general, the swelling pressure reached a constant value after a few days.

The similar tests were also performed on compacted powder specimens. The powder was prepared by milling the rock material in an agate stone mill and sieving to a maximum grain size of $0.25 \mathrm{~mm}$. The powder was pressed into the oedometer ring using a piston of an uniaxial testing machine. The load (approx. 200kN) was kept constant for about one

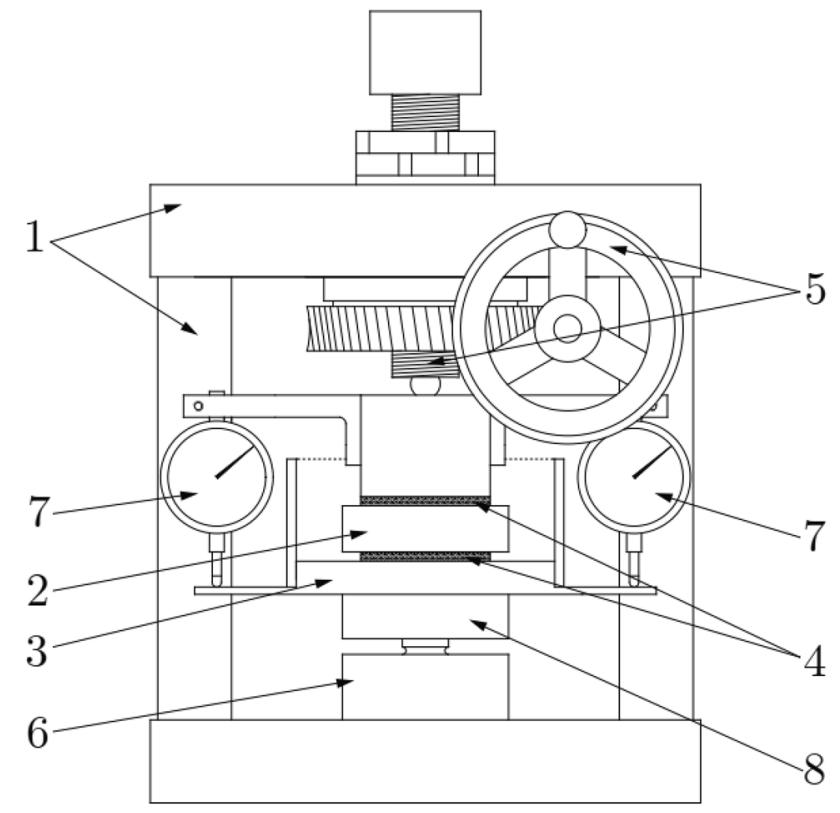

Fig. 2 Apparatus for performing oedometer swelling tests (1) Rigid frame, (2) ring and specimen, (3) watering cell, (4) porous metal sintered plates, (5) manual spindle, (6) load cell and (7) dial gauges (Vergara and Triantafyllidis 2015)

hour. The density of the prepared powder samples is in general lower than that of the intact rock, which is around $2.6 \mathrm{~g} / \mathrm{cm}^{3}$. It is underlined here that the powder tests were mainly conducted for comparison purposes to investigate the influence of the rock structure in the swelling behavior and to check whether this "quick version" of swelling tests is appropriate in the investigation of rock swelling.

The cyclic swelling tests followed a procedure in which the samples were exposed to repeated cycles of wetting and drying, at stages with different levels of deformation. Each swelling-drying cycle followed the same procedure, where the pressure development under swelling and drying was measured over time, while the deformation level was kept constant. After the swelling pressure reached a constant value in a cycle, the water was removed and the specimen was left to dry at $20{ }^{\circ} \mathrm{C}$ and at a relative humidity of $40 \%$ until no further reduction of the pressure was measured. The same water used in the previous cycle was poured again into the vessel. Water loss by evaporation was refilled to maintain the same water level in the watering cell. The deformation of the specimen was adjusted before the peak pressure was reached during wetting so that prescribed deformation level was maintained. No deformation adjustment was made in the dry state.

The first stage of the test consisted of a maximum swelling pressure test at zero deformation. In the second stage, a non-zero deformation level was applied. It was observed that the peak swelling pressure at a given level 
of deformation rised from cycle to cycle, until reaching a constant level. As soon as an asymptotic peak swelling pressure was estimated from the cycles, a new stage (new deformation level) followed. The procedure was repeated for several stages with increasing deformation levels.

\section{Achieved Results}

\subsection{XRD- and Thin-Section Analysis Results}

The mineralogical composition was assessed by XRD analysis. The textural features of the rock, including mineral characteristics, grain size, estimated porosity, microfracturing and clay distribution were determined by the thin-section analyses. The clay content is estimated based on the observed swelling minerals from the thin-section analysis. Furthermore, a qualitative estimation of the swelling potential was performed based on mineralogical and textural characteristics.

\subsection{Flysch Rocks}

The XRD results show that the flysch samples hold a moderate content of quartz, chlorite and calcite, a low feldspar content and relatively high contents of amorphous phases and swelling clays. An overview of the main results obtained from the thin-section analysis of the flysch rocks is given in Table 3. Some examples of the images of the thin sections are presented in Fig. 3.

\subsection{Volcanic Rocks}

Based on the XRD results, all the volcanic rocks show high contents of silica minerals as plagioclase, pyroxenes and quartz, which are typical forming minerals of igneous rocks. Some samples show alteration- and weathering products such as laumontite, clay minerals and chlorites. The content of amorphous phases is very high. The content of swelling minerals is uncertain as detected swelling minerals may be masked by other mineral peaks in the XRD diffractogram and may also be present as intermediate constituents of the amorphous phases. However, possible swelling clay minerals are observed in the thin sections. An overview of the main results obtained from the thin sections of the volcanic rocks is given in Table 4 . Some examples of the images of thin sections are presented in Fig. 4.

\subsection{Oedometer swelling test results}

\subsubsection{Maximum Swelling Pressure}

The results of the maximum swelling pressure tests (maximum swelling pressure at zero deformation), the density of both powder and intact rock specimens (first cycle of the cyclic swelling tests) and indications on initial water content of the intact rocks are presented in Table 5.

\subsubsection{Cyclic Tests with Controlled Deformation}

Results of the equilibrated deformation and pressure reached at the wet phase of each cycle for flysch and volcanic rocks are shown in Figs. 5 and 6, respectively. The swelling pressure in the first cycle corresponds to the standard maximum

Table 3 Main textural and fracture characteristics of the flysch rocks including estimations of clay content, visible porosity and swelling potential of the intact rock specimen

\begin{tabular}{|c|c|c|c|c|c|}
\hline Sample & Texture & $\begin{array}{l}\text { Estimated } \\
\text { clay con- } \\
\text { tent }\end{array}$ & Fracture characteristics* & Estimated porosity & $\begin{array}{l}\text { Estimated } \\
\text { swelling } \\
\text { potential }\end{array}$ \\
\hline Flysch C & $\begin{array}{l}\text { Finely laminated micrite with dispersed } \\
\text { calcite microspar }\end{array}$ & $15-20 \%$ & $\begin{array}{l}\text { Mainly calcite cemented } \\
\text { Some very thin clay-filled microfractures } \\
\text { Low permeability }\end{array}$ & $<0.5 \%$ & Medium \\
\hline Flysch D & $\begin{array}{l}\text { Laminated mudstone with sandy layers. } \\
\text { Concentrated, lenticular clay aggre- } \\
\text { gates within the laminations }\end{array}$ & $\sim 40 \%$ & $\begin{array}{l}\text { Open microfractures with parallel } \\
\text { cleavage defined by clay aggregates, } \\
\text { chlorite and mica. Some calcite as } \\
\text { intergranular cement } \\
\text { Low-medium permeability }\end{array}$ & $\sim 1 \%$ & High \\
\hline Flysch E & $\begin{array}{l}\text { Distinct turbidite lamination included } \\
\text { fine lamina of micrite, clay aggregates } \\
\text { and sand }\end{array}$ & $\sim 40 \%$ & $\begin{array}{l}\text { Carbonate cemented fractures transect- } \\
\text { ing matrix. Thin, open fractures and } \\
\text { voids in cemented fractures } \\
\text { Medium permeability }\end{array}$ & $\sim 2 \%$ & Medium-high \\
\hline
\end{tabular}

*Fractures may have been slightly dilated during sampling 

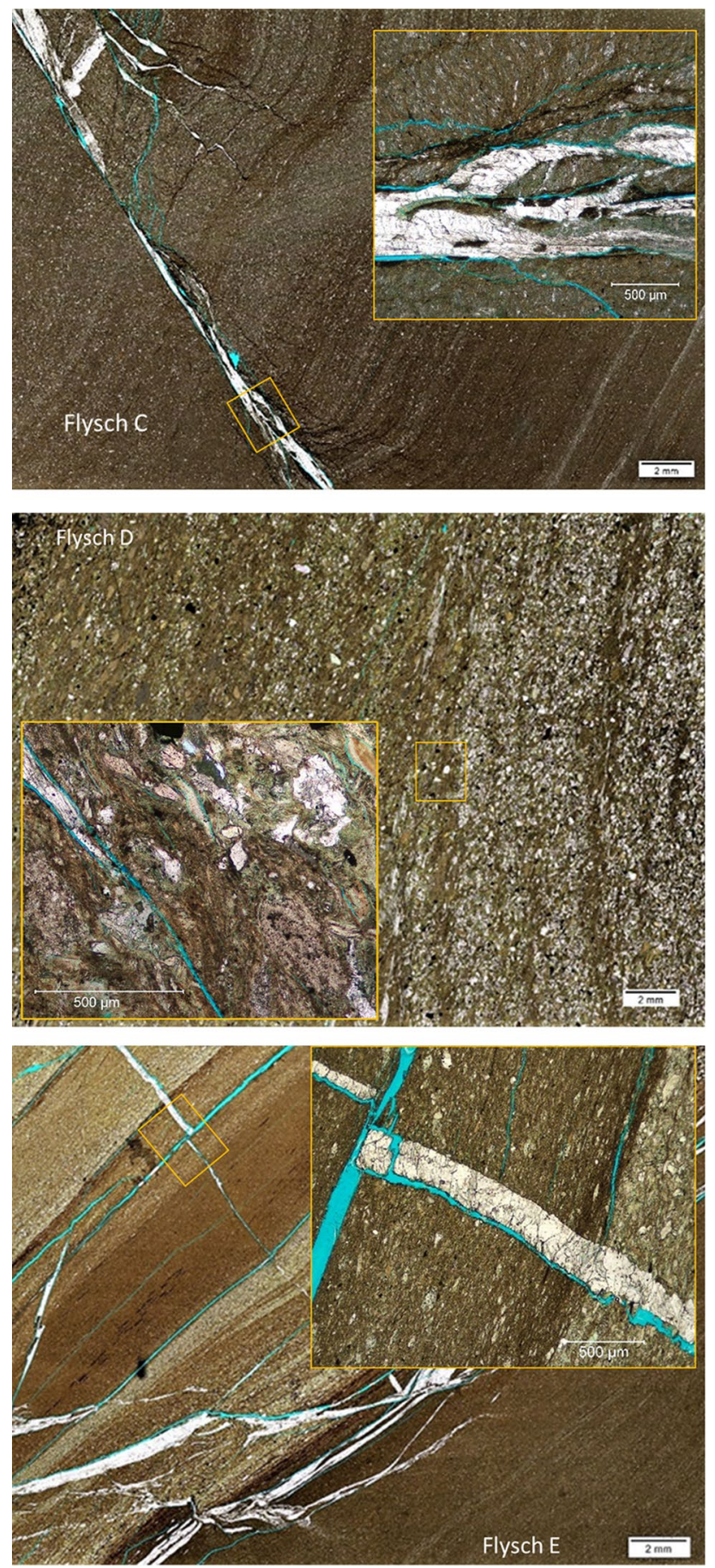

Fig. 3 Thin-section scans of Flysch C-E, including magnifications of fracture details (yellow boxes) (color figure online)

swelling pressure tests. The specimens Volcanic B and Volcanic D did not swell nor reacted to the cyclic wetting and were terminated after three test cycles.

\section{Analysis of the Results}

\subsection{Relationship Between Swelling Pressure, Critical Minerals and Petrographic Data}

\subsubsection{The Flysch Rocks}

While carrying out swelling pressure tests, only 3 out of 7 flysch samples (Flysch C, Flysch D and Flysch E) could be tested as intact and as pulverized rock sample. Since the remaining flysch samples were highly weathered and weak, no thin sections or intact rock specimen could be prepared. The summary of the potential swelling and respective content of critical minerals possibly leading to swelling, in addition to calcite which may prevent swelling to occur, are presented in Table 6 .

As indicated in Table 6, the swelling extent of rocks not only depend on the content of detected swelling clay minerals but is also influenced by the content of amorphous material. Higher the content of swelling clay and amorphous material in the rock, higher is the swelling potential.

The swelling potential of samples Flysch D and E are high and medium-high, respectively. The test on intact rock sample Flysch E developed a higher pressure. Comparison made with the petrographic data shows that Flysch E contains mud-sized calcite within clay matrix, whereas sample Flysch D is coarse-grained and includes some of the calcite as intergranular cement (Table 3). This cementation may have inhibited the swelling. When crushing the rock to powder the cementation is destroyed and the actual swelling potential may have developed, resulting in a distinct increase in swelling pressure. It is interesting to note that the intact sample Flysch $\mathrm{E}$ shows much higher swelling pressure than the powder sample, suggesting that the structural features of this rock have a strong effect on the swelling behavior.

\subsubsection{The Volcanic Rocks}

The XRD analysis indicates high contents of amorphous minerals in all the samples, which is supported by microscopy observations of variably altered volcanic glass and matrix in the rocks. The most distinct swelling is seen in the heterogeneous volcanic breccias, (samples Volcanic $\mathrm{E}$ and Volcanic F) which are rich in glassy fragments as well as swelling clay in matrix. The estimated swelling potential, based on the textural and fracture characteristics, estimations of clay content and visible porosity of the intact rock specimen, correlates well with the laboratory measured swelling pressures for most of the volcanic rocks. The summary of the potential swelling and 


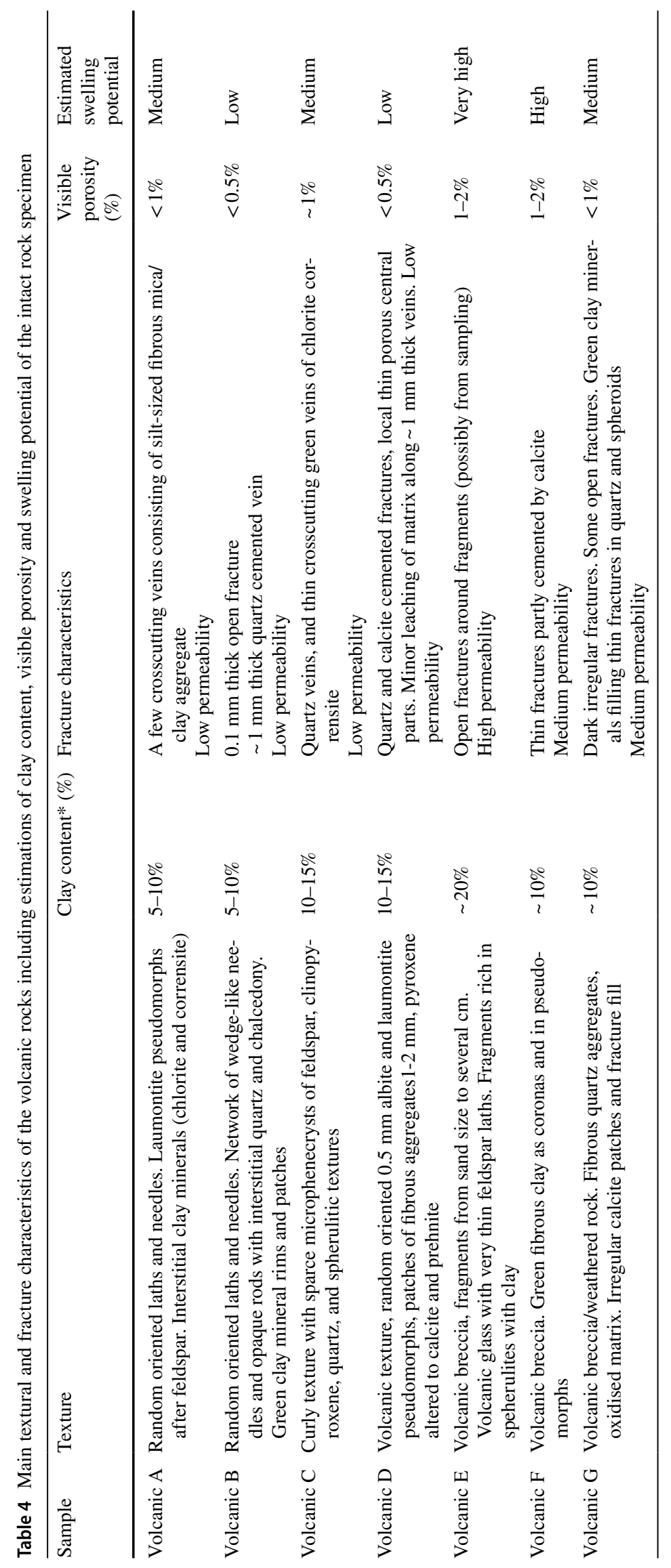



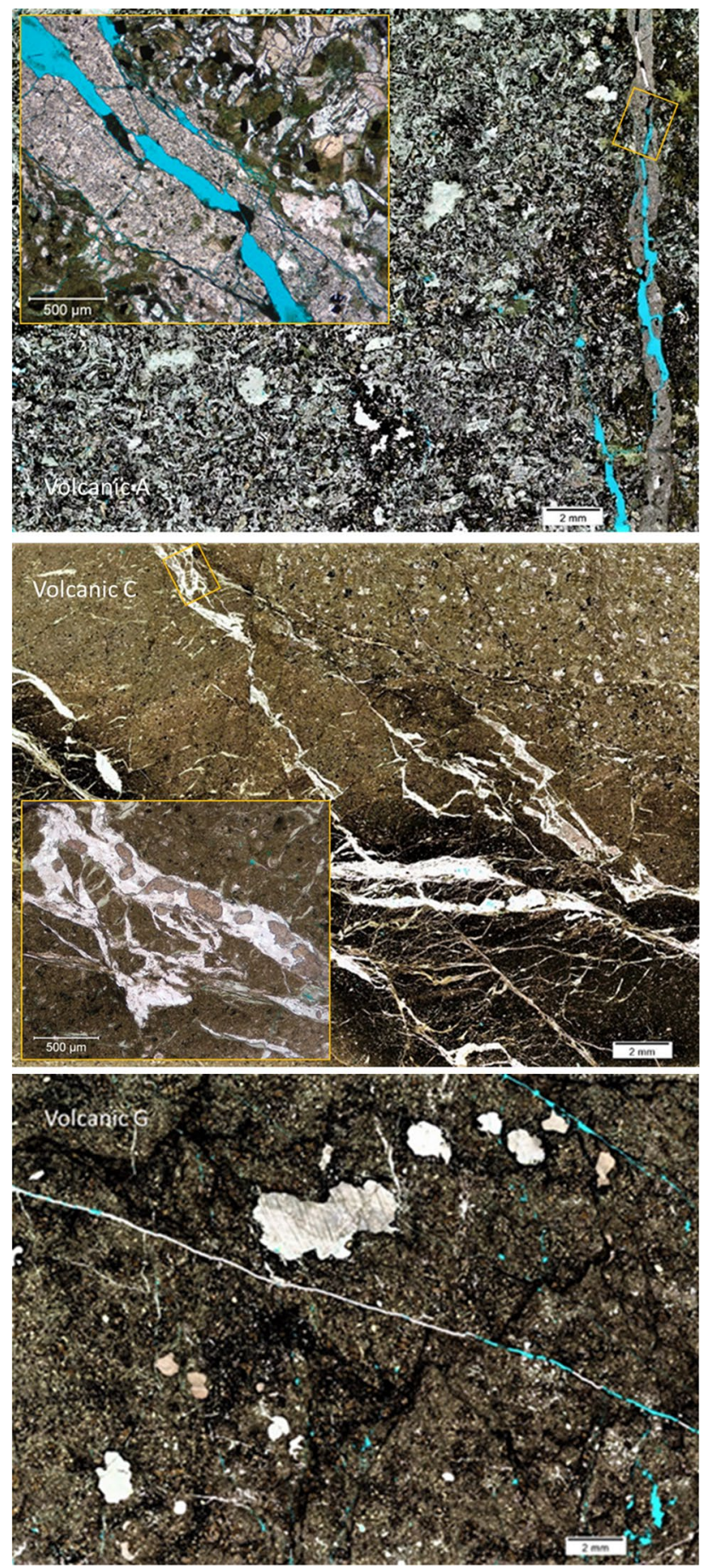

Fig. 4 Thin-section scans of Volcanic A, Volcanic C and Volcanic G, including magnifications of fracture details (yellow box) (color figure online)

respective content of critical minerals possibly leading to swelling is presented in Table 7, including the content of calcite which may prevent swelling to occur.

As one can see in Table 7, the result of the measured swelling pressure and mineralogical composition indicates a distinct link between swelling behavior and amount of amorphous, as well as laumontite minerals. The measured swelling pressures of the pulverized samples are higher than the swelling pressures of the intact rock samples.

Sample Volcanic A is an apparently homogeneous volcanic rock with a very high content of laumontite (31\%) and amorphous constituents (45\%). The XRD analysis did not indicate any swelling clay minerals (Table 7); however, the thin-section analysis clearly identifies potential swelling clay minerals in the rock structure (Table 4). The specimen reached high swelling pressure in both pulverized and intact rock samples. Considerable amount of both laumontite and amorphous material is suspected to be among the main reasons for this high swelling potential. According to Bravo et al. (2017) the content of laumontite in sedimentary and crystalline rocks is usually not considered to produce considerable swelling but laumontite present in volcanic rocks has been found to be responsible for rock swelling and subsequent damage of a hydropower water tunnel. The test results of this study confirm this finding, where the presence of laumontite seems very influential in aggravating swelling.

The samples Volcanic C, E and F have high content of amorphous minerals. From the thin-section analysis, their swelling potential was estimated as medium, very high and high, respectively. When tested as intact rock, they show relatively low maximum swelling pressure. It is observed that after grinding the sample and destroying their fabric, the swelling potential could develop resulting in high swelling pressure confirming the initial estimation of the swelling potential. Samples $\mathrm{C}$ and $\mathrm{F}$ were very reactive to the cyclic wetting and drying, showing a significant increase in swelling pressure with the number of cycles. This may be explained by uneven distribution of swelling clay in the matrix, i.e., the concentration of swelling clay as aggregates in the matrix and/or as fracture infillings.

The sample Volcanic G, for which only medium swelling potential was estimated, showed a strong increase in swelling pressure in the cyclic test. The thin-section analysis shows green clay minerals filling with thin fractures in quartz and spheroids. The textural/structural properties of the rock may have interacted with the swelling minerals, resulting in a combination of chemical and physical swelling.

\subsection{Analysis of Cyclic Swelling Tests}

Grob (1972) suggested that there is a logarithmic link between swelling strain (axial deformation) and swelling pressure, which is expressed by Eq. 1 (swelling curve). In this equation, $K$ is a material constant, $\sigma_{0}$ corresponds to the swelling pressure at zero deformation and $\sigma$ corresponds to the pressure at increased deformation: 
Table 5 Results of the oedometer swelling tests on both pulverized and intact rock specimen, including the measured initial water content of the intact rock and the measured densities of all samples

\begin{tabular}{|c|c|c|c|c|c|c|}
\hline \multirow[t]{2}{*}{ Rock type } & \multirow[t]{2}{*}{ Specimen } & \multirow[t]{2}{*}{$\begin{array}{l}\text { Initial moisture con- } \\
\text { tent, intact samples }(\%)\end{array}$} & \multicolumn{2}{|c|}{ Density $\left(\mathrm{g} / \mathrm{cm}^{3}\right)$} & \multicolumn{2}{|c|}{$\begin{array}{l}\text { Maximum Swelling } \\
\text { Pressure (MPa) }\end{array}$} \\
\hline & & & $\begin{array}{l}\text { Compacted } \\
\text { powder }\end{array}$ & Intact rock & $\begin{array}{l}\text { Compacted } \\
\text { powder }\end{array}$ & Intact rock \\
\hline \multirow[t]{7}{*}{ Flysch } & Flysch A & - & 2.11 & - & 0.53 & - \\
\hline & Flysch B & - & 2.15 & - & 0.29 & - \\
\hline & Flysch C & 2.6 & 2.16 & 2.58 & 0.66 & 0.46 \\
\hline & Flysch D & 7.2 & 2.32 & 2.50 & 4.13 & 0.91 \\
\hline & Flysch E & 3.8 & 2.18 & 2.47 & 1.50 & 3.79 \\
\hline & Flysch F & - & 2.15 & - & 0.61 & - \\
\hline & Flysch G & - & 2.06 & - & 0.18 & - \\
\hline \multirow[t]{7}{*}{ Volcanic } & Volcanic A & 1.2 & 1.87 & 2.60 & 4.9 & 2.08 \\
\hline & Volcanic B & 1.9 & 1.98 & 2.76 & 0.4 & 0.05 \\
\hline & Volcanic C & 1.4 & 1.99 & 2.66 & 2.4 & 0.13 \\
\hline & Volcanic D & 0.6 & 1.94 & 2.82 & 0.4 & 0.04 \\
\hline & Volcanic E & 5.0 & 1.95 & 2.32 & 3.0 & 0.38 \\
\hline & Volcanic F & 5.5 & 1.69 & 2.26 & 2.9 & 0.17 \\
\hline & Volcanic G & 1.9 & 1.92 & 2.50 & 0.8 & 0.49 \\
\hline
\end{tabular}
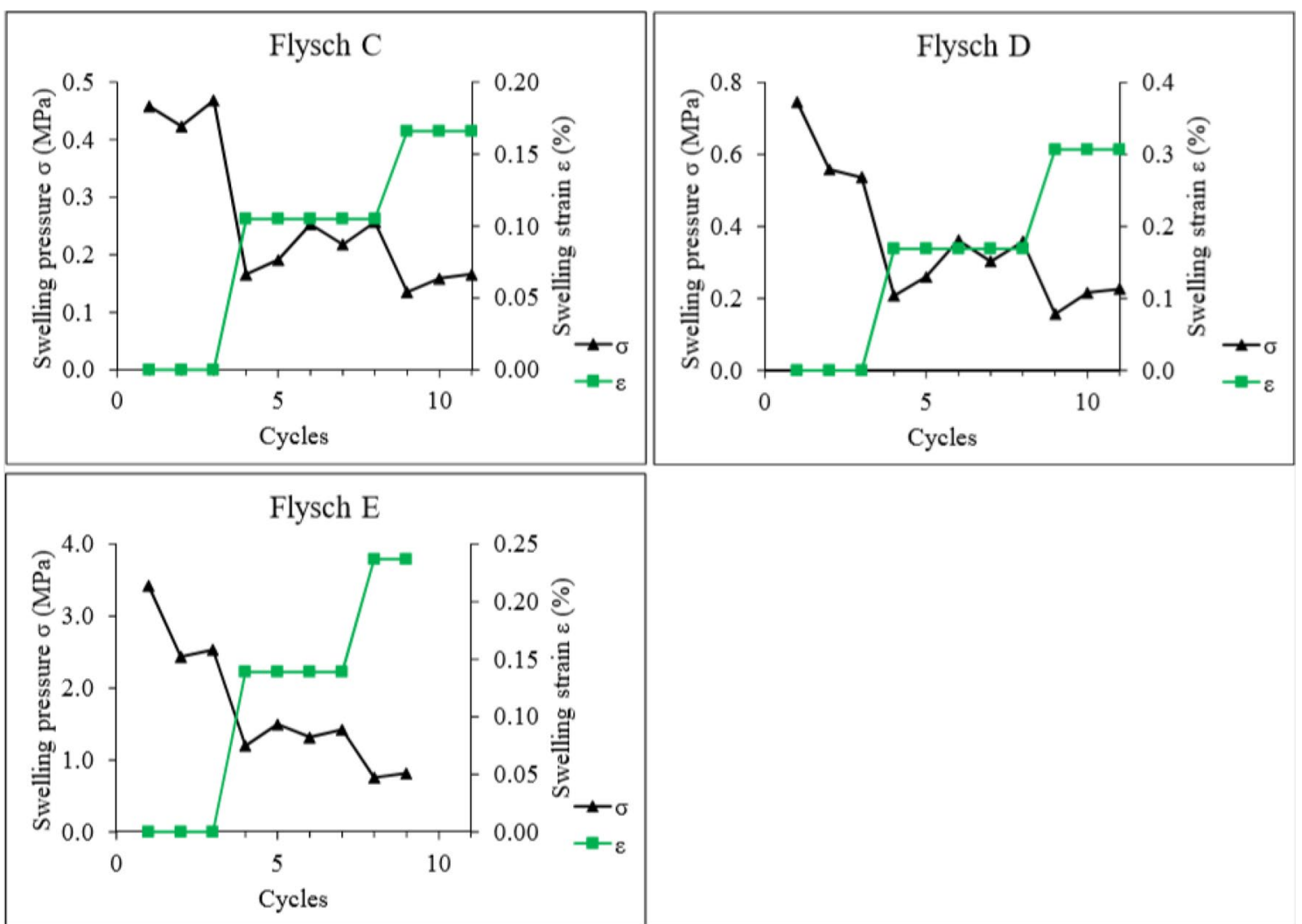

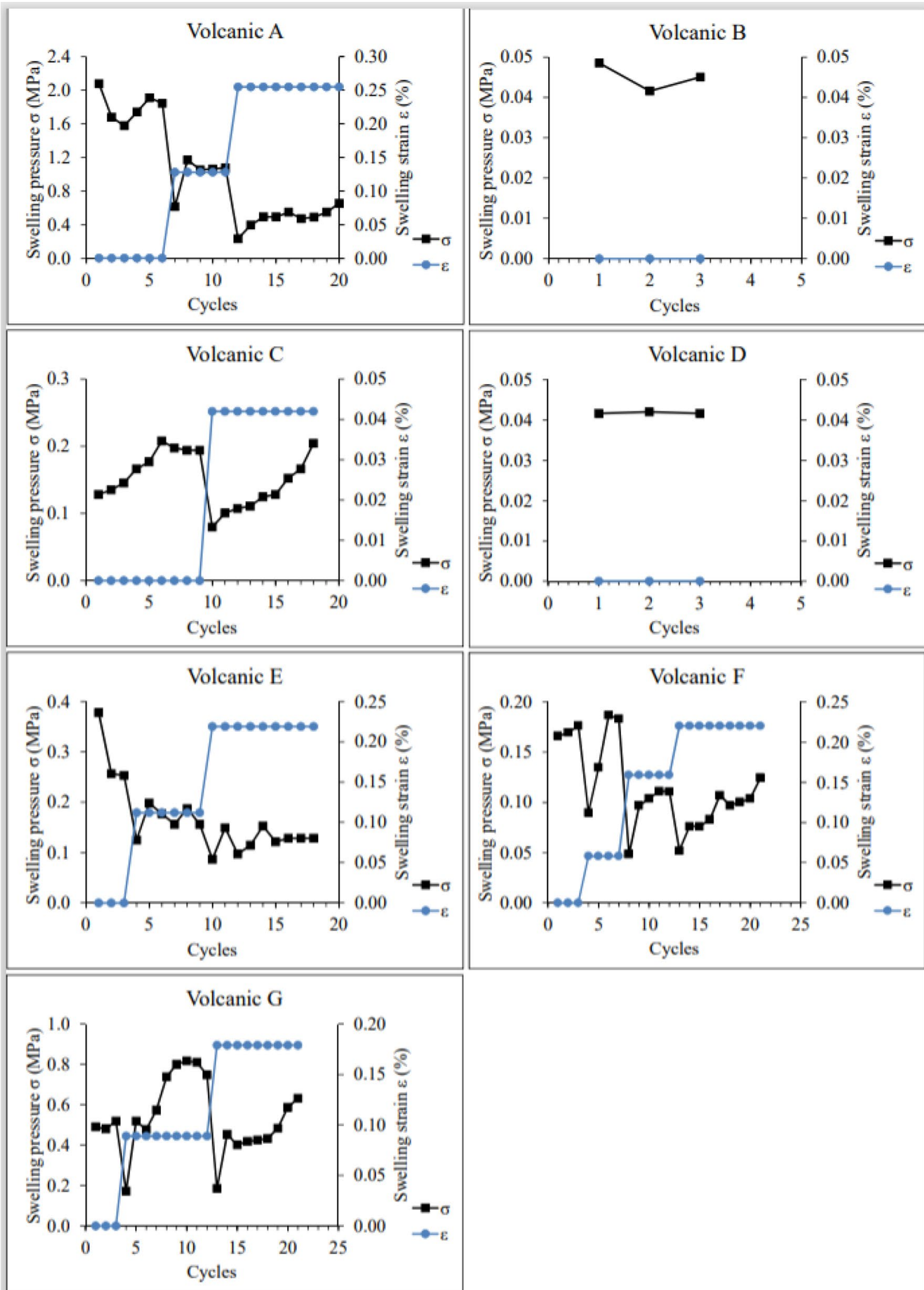

Fig. 6 Evolution of swelling pressure and strain with number of wetting cycles in oedometer test on volcanic rock specimens 
Table 6 Summary of measured maximum swelling pressure (MPa) and critical minerals from XRD of the flysch rocks. The XRD analysis is performed at KIT

\begin{tabular}{|c|c|c|c|c|c|c|c|}
\hline \multirow[t]{2}{*}{ Sample } & \multicolumn{3}{|c|}{ Swelling potential } & \multicolumn{4}{|c|}{ Critical minerals from XRD ( $\%$ mass $)$} \\
\hline & $\begin{array}{l}\text { Estimated from } \\
\text { thin section }\end{array}$ & $\begin{array}{l}\text { Lab tested pressure for } \\
\text { intact rock }(\mathrm{MPa})\end{array}$ & $\begin{array}{l}\text { Lab tested pressure, for } \\
\text { rock powder }(\mathrm{MPa})\end{array}$ & Amorphous & Chlorite & Swelling clay & Calcite \\
\hline Flysch A & - & - & 0.53 & 19 & 22 & 24 & 9 \\
\hline Flysch B & - & - & 0.29 & 14 & 22 & 9 & 19 \\
\hline Flysch C & Medium & 0.46 & 0.66 & 9 & 11 & 5 & 41 \\
\hline Flysch D & High & 0.91 & 4.13 & 22 & 3 & 32 & 19 \\
\hline Flysch E & Medium-high & 3.79 & 1.50 & 22 & 18 & 26 & 13 \\
\hline Flysch F & - & - & 0.61 & 18 & 19 & 20 & 19 \\
\hline Flysch G & - & - & 0.18 & 10 & 8 & 8 & 53 \\
\hline
\end{tabular}

Table 7 Summary of measured swelling pressure (MPa) and critical minerals from XRD of the volcanic rocks. The XRD analysis was performed at NTNU

\begin{tabular}{|c|c|c|c|c|c|c|c|c|}
\hline \multirow[t]{2}{*}{ Sample } & \multicolumn{3}{|l|}{ Swelling potential } & \multicolumn{5}{|c|}{ Critical minerals from XRD $(\%)$} \\
\hline & $\begin{array}{l}\text { Estimated } \\
\text { from thin section }\end{array}$ & $\begin{array}{l}\text { Lab. tested pressure } \\
\text { for intact rock (MPa) }\end{array}$ & $\begin{array}{l}\text { Lab. tested pressure } \\
\text { for powder }(\mathrm{MPa})\end{array}$ & Amorph & Chlorite & Swell. clay* & Calcite & Laumontite \\
\hline Volcanic A & Medium & 2.08 & 4.9 & 45 & 2 & - & - & 31 \\
\hline Volcanic B & Low & 0.05 & 0.04 & 44 & 5 & - & - & 2 \\
\hline Volcanic C & Medium & 0.13 & 2.4 & 46 & 12 & u.a & - & 8 \\
\hline Volcanic D & Low & 0.04 & 0.4 & 29 & 9 & - & 4 & 1 \\
\hline Volcanic E & Very high & 0.38 & 3.0 & 53 & - & u.a & 8 & 3 \\
\hline Volcanic F & High & 0.17 & 2.9 & 58 & - & u.a & 1 & - \\
\hline Volcanic G & Medium & 0.49 & 0.8 & 40 & 5 & u.a & 4 & 4 \\
\hline
\end{tabular}

*The amount of swelling clay is unknown (u.a= "unknown amount")

the swelling pressure increased during cycling, recovering the reduction produced by the unloading. This results in a steeper curve, which means higher pressure compared to that would be found in a conventional test.

In some cases, a drop of the pressure was observed between the first and subsequent cycles under zero deformation (first stage). This may have been caused by differences between the initial water content and the water content reached in the testing room during the drying phase. Differences in the initial water content of the same rock will produce different swelling pressure.

Even if the swelling curves of all samples were affected by the cyclic wetting and drying, becoming steeper, all three tested rock samples of flysch show the general trend of decreased pressure upon increased strain (Fig. 5). However, the samples Volcanic C, Volcanic F and Volcanic G showed almost an opposite behavior, whereby the swelling pressure increased beyond to the level of zero deformation once deformation was allowed and kept constant (Fig. 6). In other words; by repeating the cycles of wetting and drying, the measured pressure after allowing axial expansion was higher than that reached under zero deformation. This is contrary to that expected according Grob's swelling law, which relates lower swelling pressure to higher deformation. The swelling strain and pressure of the equilibrium points of each cycle are shown in Fig. 7, where standard swelling pressure tests at zero deformation correspond to the first equilibrium point of the cyclic tests.

\section{Discussion}

\subsection{XRD- and Thin-Section Analyses in Swelling Rock Assessments}

Estimation of the amorphous content is extremely important in quantifying mineral constituents so that degree of weathering of the rock material is well understood. The main drawback with XRD is the poor recognition of amorphous phases lacking crystalline order. In addition, different procedures in analyzing XRD results are found between institutions, which have major implications on the results when the weathering extent is high in the samples. On the other hand, thin-section analysis 
Fig. 7 Swelling strain (\%) vs. swelling pressure (MPa) for flysch (top) and volcanic rock (bottom) specimens
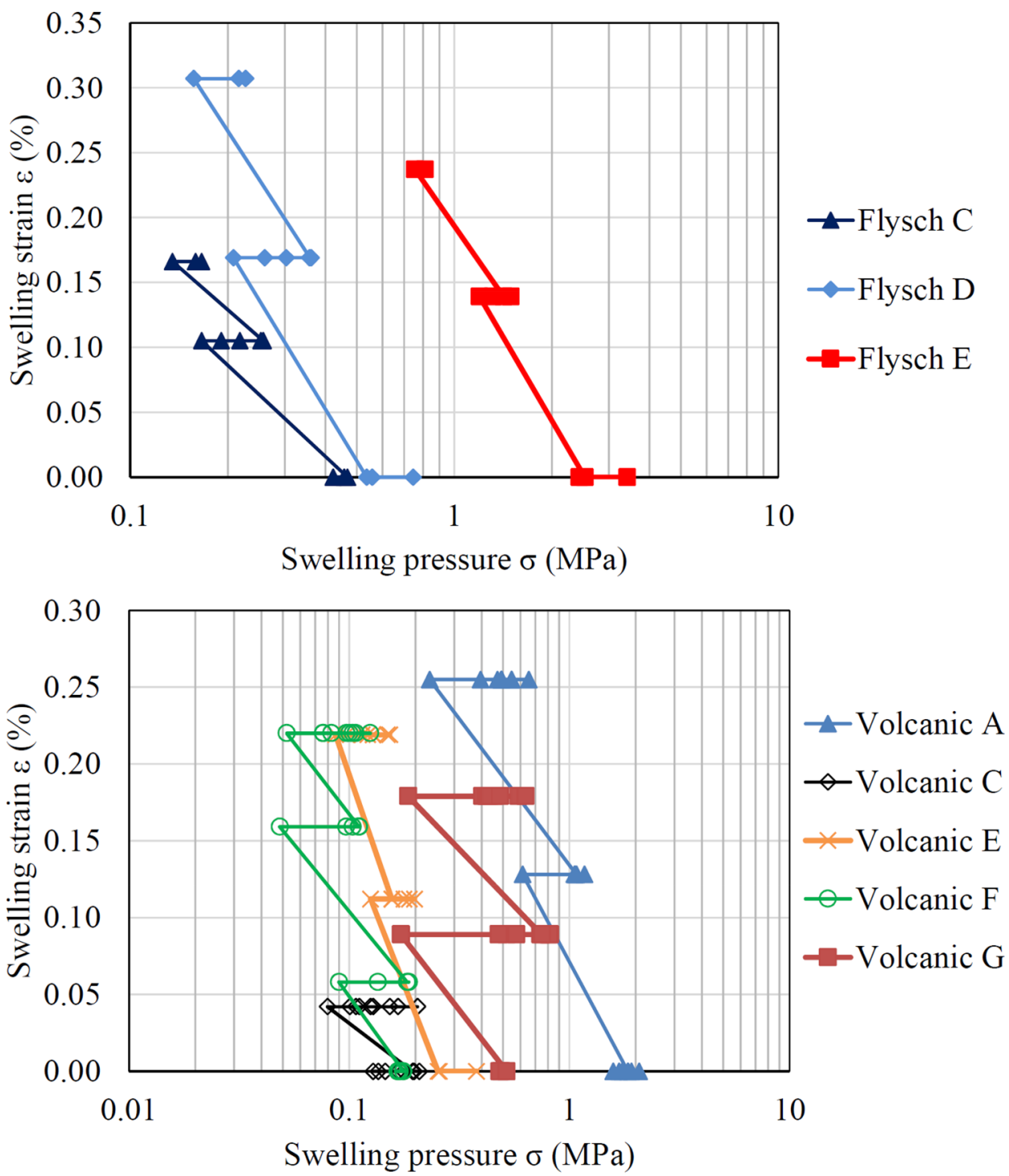

enables a qualitative assessment of the mineralogical and textural features of the rock, which can be compared to the quantitative estimations of mineral constituents from the XRD analysis. The distribution of minerals and fracture characteristics can be observed, which have important implications on the rock behavior when exposed to water. In addition, the amorphous content can be assessed and identified based on optical properties.

This study revealed major deviations between the XRD results and the thin-section descriptions of several samples. The deviations are mainly related to the estimation of clay in the tested samples. This may be due to the coexisting amorphous and clay-sized constituents, which is not easily separated. It is assumed that the amorphous content includes swelling mineral phases that are not detected by traditional methods. Still, the estimation of swelling potential based on the combination of XRD and thin-section analyses correlates well with the measured swelling pressure in the oedometer tests.

\subsection{Comments on the Oedometer Swelling Tests}

The main advantage of oedometer swelling pressure tests on powder samples is that it is quick, straight-forward and not dependent on rock quality. The test results are given in the form of swelling pressure, and they indicate whether the rock has a swelling potential or not. On the other hand, the intact rock may behave very differently compared to the pulverized samples due to structural/textural properties, differential density and differential distribution 
of swelling minerals. These drawbacks can have major implications on the applicability of the results and hence the swelling pressure test results obtained from powder samples, are conservative results and should be taken as index tests only.

The cyclic swelling test results of intact rock samples, where changes in deformation and moisture content are allowed (Figs. 5 and 6), have shown that the textural/structural features of the intact rock may interact with swelling minerals on the swelling behavior. In some cases, the observed porosity and low density of the rocks indicate a weak structure, which can easily degrade during repeated wetting and drying, leading to disintegration on a long-term perspective and consequently further activating swelling in the rock.

Caution is required for rock types holding a potential for high swelling pressure when exposed to changes in boundary conditions, i.e., allowed deformation and repeated cycles of wetting and drying, as this behavior may be connected to physical swelling mechanisms of the rock, which are not recognizable by XRD or powder swelling tests. Rock types which have a heterogeneous texture, uneven distribution of swelling clay minerals and open and/or clay-filled microfractures show a tendency to higher swelling potential with repeated moisture changes compared to rock types with a homogeneous texture. These findings are important knowledge on support evaluations of water conveying (headrace and tailrace) tunnels of hydropower projects that experience changes at different stages of their life cycle. For example, a headrace tunnel passing through weak rock mass having swelling minerals, first experiences unloading and complete drainage after excavation. After the completion of the excavation, the tunnel is filled with water causing complete saturation. Over the lifetime of the project, the headrace tunnel will experience changes in pressure, and it will be dewatered and filled again several times, which could result in changes of the rock mass properties.

The cyclic tests revealed that Grob's law is not valid for the case of cyclic swelling. This is presumably caused by degradation of weaker rock structures during the wetting and drying cycles (Fig. 7). This degradation makes the rock not comparable to that in a previous deformation stage. In some cases, the swelling potential instead increases after allowing expansion. With such a swelling behavior, the swelling curve of the rock is unknown, and it is not possible to calculate an equilibrium state of swelling pressure and deformation (strain). This has implications on the design of water tunnels, where the design of required support is based on the estimated swelling pressure and deformation of the tunnel lining.

\section{Conclusions}

- The XRD analysis is not a proper method for describing weathered and swelling rock compositions unless it is complemented with thin-section analysis, which considers other features of the minerals to describe their origin and their characteristics.

- Heterogeneous rocks with uneven distribution of swelling clay minerals and open and/or clay-filled microfractures may hold a higher swelling potential compared to rock types with a homogeneous texture.

- Structural breakdown and disaggregation of the intact rock may occur during cyclic swelling, allowing a greater volume of swelling minerals to adsorb water in the next wetting cycle. The location of the swelling minerals within the rock texture seem to play an important role and underlines the importance of performing swelling tests on intact rock and to analyze the structure of the rock to assess the swelling characteristics of rocks containing even low amounts of swelling minerals.

- Significant physical swelling can develop even for small concentrations of swelling clay. Induced and/or advancing microfractures in the rock due to allowed deformation during cyclic wetting may lead to alteration of the rock properties. The relation between swelling strain and stress proposed by Grob (1972) is therefore not valid in the case of swelling affected by cyclic wetting.

- None of the applied methods, when applied isolated, can assess the swelling potential of rocks, but the combination of the different methods gives a fair estimation on the swelling behavior.

- The cyclic swelling test carried out on intact rock represent a condition closer to the in-situ condition of a water tunnel when compared to the standard swelling test and is recommended to be adopted for swelling tests in future hydropower projects.

Funding Open Access funding provided by NTNU Norwegian University of Science and Technology (incl St. Olavs Hospital - Trondheim University Hospital)

Open Access This article is licensed under a Creative Commons Attribution 4.0 International License, which permits use, sharing, adaptation, distribution and reproduction in any medium or format, as long as you give appropriate credit to the original author(s) and the source, provide a link to the Creative Commons licence, and indicate if changes were made. The images or other third party material in this article are included in the article's Creative Commons licence, unless indicated otherwise in a credit line to the material. If material is not included in the article's Creative Commons licence and your intended use is not permitted by statutory regulation or exceeds the permitted use, you will 
need to obtain permission directly from the copyright holder. To view a copy of this licence, visit http://creativecommons.org/licenses/by/4.0/.

\section{References}

Banfield JF, Eggleton RA (1990) Analytical transmission electron microscope studies of plagioclase, muscovite, and K-feldspar weathering. Clays Clay Miner 38:77-89. https://doi.org/10.1346/ CCMN.1990.0380111

Bravo A, Jerez O, Kelm U, Poblete M (2017) Dehydration-hydration reactivity of laumontite: analyses and tests for easy detection. Clay Miner 52(3):315-327. https://doi.org/10.1180/claym in.2017.052.3.03

Dick JC, Shakoor A (1992) Lithological controls of mudrock durability. Q J Eng GeolHydrogeol 25(1):31-46

Einstien H (1994) Comments and recommendations on design and analysis procedures for structures in argillaceous swelling rock. In: International Journal of Rock Mechanics and Mining Sciences and Geomechanics Abstracts. Oxford; New York: Pergamon Press, 1974-c1996: 535-546.

Grob H (1972) Schwelldruck im Belchentunnel. Proc. Int. Symposium on Underground Opening, Lucerne: 99-119

ISRM (1979) Suggested methods for determining water content, porosity, density, absorption and related properties and swelling and slake-durability index properties. Int J Rock Mech Min Sci Geomech Abstr 16(2):143-151. https://doi.org/10.1016/01489062(79)91452-9

ISRM (1989) ISRM commission on swelling rocks. Suggested methods for laboratory testing of argillaceous swelling rock. Int J Rock Mech Min Sci Geomech Abstr Res 26(5):415-426
ISRM (1999) ISRM commission on swelling rocks. 1999. Suggested methods for laboratory testing of swelling rocks. Int J Rock Mech Min Sci Geomech Abstr Res 36(3):291-306

Olivier HJ (1991) Some aspects of the engineering-geological properties of swelling and slaking mudrocks, In: Proceedings of 6th International IAEG Congress. Rotterdam: 707-711

Ruedrich J, Bartelsen T, Dohrmann R, Siegesmund S (2010) Moisture expansion as a deterioration factor for sandtsone used in bulidings. Environ Earth Sci 63:1545-1564. https://doi.org/10.1007/ s12665-010-0767-0

Russell DJ (1982) Controls on shale durability: the response of two Ordovician shales in the slake durability test. Can Geotech J 19(1):1-13. https://doi.org/10.1139/t82-001

Selen L, Panthi KK, Vistnes G (2019) An analysis on the slaking and disintegration extent of weak rock mass of the water tunnels for hydropower project using modified slake durability test. Bull Eng Geol Environ 79(4):1919-1937. https://doi.org/10.1007/s1006 4-019-01656-2

Vergara MR, Triantafyllidis T (2015) Swelling behavior of volcanic rocks under cyclic wetting and drying. Int J Rock Mech Min Sci 80:231-240. https://doi.org/10.1016/j.ijrmms.2015.08.021

Publisher's Note Springer Nature remains neutral with regard to jurisdictional claims in published maps and institutional affiliations. 